腹腔鏡下に診断，治療が行えた穿孔性回腸重複腸管の 1 例

\begin{tabular}{|c|c|c|c|c|c|c|c|}
\hline \multicolumn{8}{|c|}{ 刈谷豊田総合病院外科 } \\
\hline 宮井 & 博隆 & 早川 & 哲史 & 清水 & 保延 & 田中 & 守嗣 \\
\hline 谷村 & 愼哉 & 山本 & 稔 & 森本 & 守 & 坪井 & 謙 \\
\hline E藤 & 崇文 & 斉藤 & 健太 & & & & \\
\hline
\end{tabular}

症例は 38 歳の男性で, 突然の腹痛を主訴に当院救急外来を受診した．腹部全体に圧痛，反跳 痛を認め, 腹部は板状硬であった，腹部 CT では臍のやや左側に炎症を伴った直径約 $4 \mathrm{~cm}$ の囊 胞様腫瘤構造と, 微小な腸管外のガスを認めた. Meckel 㮩室穿孔による急性汎発性腹膜炎と診 断し，同日緊急腹腔鏡下手術を施行した. 腹腔鏡で観察すると，回腸末端から約 $80 \mathrm{~cm}$ の腸間膜 側に囊胞様腫瘤を伴う憩室が存在し穿孔していた. 回腸部分切除術, 虫垂切除術を施行した. 病理組織学的検査から，囊胞様重複腸管の内部には異所性胃粘膜が一面に存在していたが，正 常腸管との連続性は認められなかった．正常腸管と連続する悡室部では異所性胃粘膜を認めな かったが腸管穿孔を来していた，穿孔性腹膜炎を契機に発症し，腹腔鏡補助下腸切除を行えた 成人の穿孔性回腸重複腸管を経験した．いくつかの文献的考察を加えて報告する.

\section{はじめに}

重複腸管 (duplications of the alimentary tract) とは舌根部から肛門に至る全消化管に発生する比 較的まれな先天性疾患である ${ }^{1)}$. ときに, 異所性胃 粘膜を持ち消化性潰瘍を来し出血, まれに穿孔を 起こすと報告されている ${ }^{2}$. 今回, 我々は穿孔性腹 膜炎を契機に発症し, 腹腔鏡補助下に腸切除を行 えた成人の穿孔性回腸重複腸管を経験したので報 告する.

\section{症例}

患者 : 38 歳, 男性

主訴 : 突然の腹痛

家族歴：特記すべきことなし.

既往歴：会社の健康診断で貧血と便潜血反応陽 性を指摘されて近医で上部消化管内視鏡検査, 下 部消化管内視鏡検査を受けたが特に異常を認めな かった。

現病歴：臍周囲の腹痛を自覚し，自宅で経過を 観察していたが, 翌日になり腹痛が増強し, 当院

$<2009$ 年 7 月 22 日受理 $>$ 別刷請求先: 宮井 博隆 T448-8505 刈谷市住吉町 5-15 刈谷豊田総合病院 外科
救急外来を受診した.

入院時現症：体格中等度, 身長 $170 \mathrm{~cm}$, 体重 65 $\mathrm{kg}$, 栄養状態良好, 血圧 $130 / 83 \mathrm{mmHg}$, 脈拍 98 回/分で整, 体温 $37.5^{\circ} \mathrm{C}$. 眼瞼結膜は軽度貧血あり, 眼球黄染なし. 腹部は平坦だが全体に板状硬で, 臍周囲に最強点となる圧痛, 筋性防御反応, 腹膜 刺激症状を認めた。

入院時血液・生化学検査所見：WBC 21,800/ $\mathrm{mm}^{3}$, Seg $94.5 \%$, CRP $1.6 \mathrm{mg} / \mathrm{dl}$ と上昇していた. $\mathrm{Hb} 10.9 \mathrm{~g} / \mathrm{dl}$ と軽度貧血も認めた. 腫瘍マーカー CEA，CA19-9 は正常範囲であった（Table 1).

胸部単純 X 線検查所見：特に異常所見なし.

腹部 $\mathrm{X}$ 線検查所見 : 腹腔内遊離ガス像なし, 鏡 面像形成は認めなかった．右下腹部骨盤内に直径 $1 \mathrm{~cm}$ 大の粪石を認めた.

腹部造影 CT 所見：臍のやや左側に $36 \times 28 \mathrm{~mm}$ 大の囊胞様腸管構造を認め, 周囲の腸間膜脂肪濃 度上昇を認めた。壁が肥厚した近傍の回腸との連 続を認めた（Fig. 1)。また，虫垂内部には $10 \mathrm{~mm}$ 大の石灰化結石を認めたが虫垂自体の炎症を認め ず，少量の腹水を Douglas 窩に認めた.

以上より, Meckel 䄭室穿孔による急性汎発性腹 
Table 1 Laboratory data on admission

\begin{tabular}{lc|lc}
\hline $\mathrm{Na}$ & $143 \mathrm{mEq} / l$ & $\mathrm{LDH}$ & $174 \mathrm{U} / l$ \\
$\mathrm{~K}$ & $4.0 \mathrm{mEq} / l$ & $\mathrm{ALP}$ & $236 \mathrm{U} / l$ \\
$\mathrm{Cl}$ & $102 \mathrm{mEq} / l$ & $\mathrm{Glu}$ & $148 \mathrm{mg} / \mathrm{dl}$ \\
$\mathrm{UN}$ & $20.4 \mathrm{mg} / \mathrm{dl}$ & $\mathrm{CPK}$ & $113 \mathrm{U} / l$ \\
$\mathrm{CRE}$ & $0.66 \mathrm{mg} / \mathrm{dl}$ & $\mathrm{CRP}$ & $1.6 \mathrm{mg} / \mathrm{dl}$ \\
$\mathrm{TP}$ & $7.1 \mathrm{~g} / \mathrm{dl}$ & $\mathrm{WBC}$ & $21,800 / \mu \mathrm{l}$ \\
$\mathrm{Alb}$ & $4.8 \mathrm{~g} / \mathrm{dl}$ & $\mathrm{Hb}$ & $12.0 \mathrm{~g} / \mathrm{dl}$ \\
$\mathrm{T}-\mathrm{Bil}$ & $0.9 \mathrm{mg} / \mathrm{dl}$ & $\mathrm{Ht}$ & $36.1 \%$ \\
$\mathrm{GOT}$ & $29 \mathrm{U} / l$ & $\mathrm{Plt}$ & $33.8 \times 10^{4} / \mu \mathrm{l}$ \\
$\mathrm{GPT}$ & $38 \mathrm{U} / l$ & Segment & $94.5 \%$ \\
\hline
\end{tabular}

Fig. 1 Abdominal enhanced CT shows that there is the elevation of intestinal mesenteric fat density and the $36 \times 28 \mathrm{~mm}$ size cystic-like structure in the left side of abdomen (arrow).

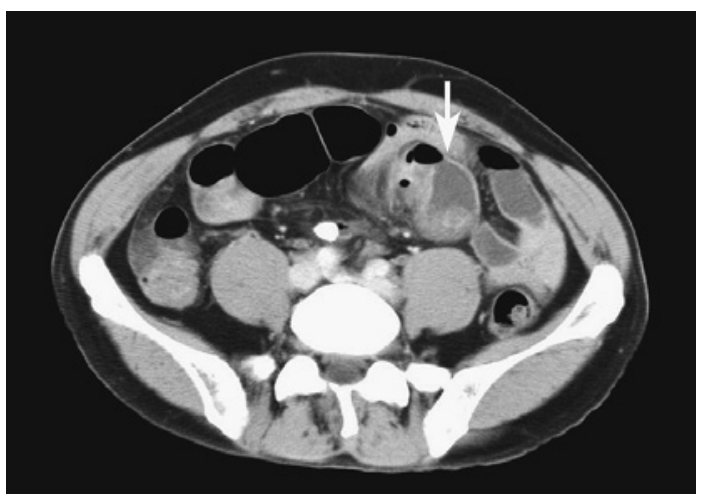

膜炎と診断し, 同日緊急腹腔鏡下手術を施行した.

腹腔鏡下手術所見：全身麻酔下に仰臥位で臍上 に $5 \mathrm{~mm}$ のカメラポートを Optical 法で挿入, 右上 腹部 $5 \mathrm{~mm}$, 左下腹部に $5 \mathrm{~mm}$ の 3 ポートとして腹 腔内を観察した．腸管全体を大網が覆っており， 鈍的に大網との癒着を剥がすと回腸末端から約 $80 \mathrm{~cm}$ の腸間膜側に囊胞様腫瘤を伴う喤室を認 め, 付着部の腸管と腸間膜を共有していた。 また, 腸管に付着する憩室の部位で穿孔していた（Fig. 2a).この観察により腸間膜側に存在し腸間膜を 共有する憩室（Fig. 2b）と判断し回腸重複腸管の 穿孔による沉発性腹膜炎と診断した。

小開腹し同部位を含む回腸約 $20 \mathrm{~cm}$ 腸切除を 行った後 (Fig. 3), 虫垂先端に糞石を認めたため 腹腔鏡下に虫垂切除術を追加し, 腹腔洗浄ドレ ナージを行った. 手術時間は 1 時間 32 分, 出血量
Fig. 2 a : Laparoscopic view 1 : There is diverticulum with the cystic-like tumor and perforated about $80 \mathrm{~cm}$ proximal from the ileum end (arrow). b : Laparoscopic view 2: There is the other side of diverticulum with the cystic-like tumor.
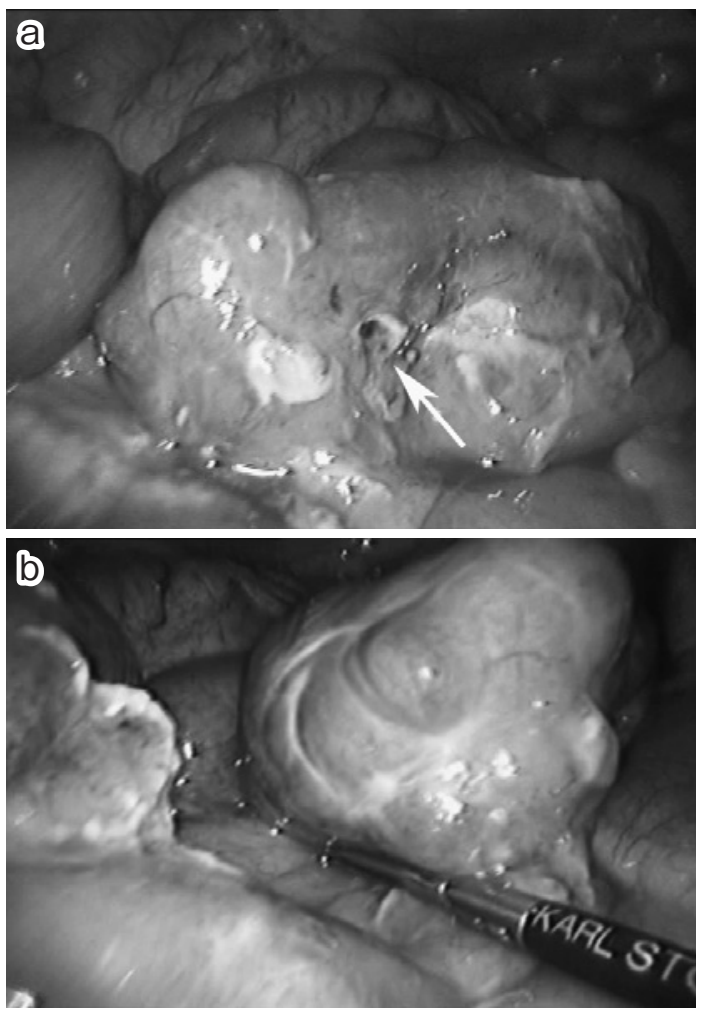

は $10 \mathrm{~g}$ であった。

切除標本 : 腸間膜側に囊胞様腫瘤を伴う喤室が 存在し, 回腸から漏斗状陥入した底部で穿孔して いた Fig. 4a)。また, 憩室は回腸と腸間膜を共有 し，血流も共有していた。

病理組織学的検査所見：正常腸管内腔から腸間 膜側に唕室が存在し，その先端には $50 \times 50 \times 40$ $\mathrm{mm}$ の球状で外部と交通を認めない, 内部に粘液 と結石を含む囊胞様腫瘤を形成していた（Fig. 4 b). また，その関係のシェーマを示す(Fig. 4c). 囊胞様腫瘤の内部には全周性に異所性胃粘膜を認 め, 付着部腸管と固有筋層を共有していた（Fig. $5 a, b)$ ．腸管から進展した憩室内部の小腸粘膜に は異所性胃粘膜を認めなかったが, この部位で穿 孔を来していた，潰瘍性変化も認めず，出血も認 
Fig. 3 After a small abdominal incision, there is a small perforated hole in the part of the diverticulum in the mesentery side (arrow).

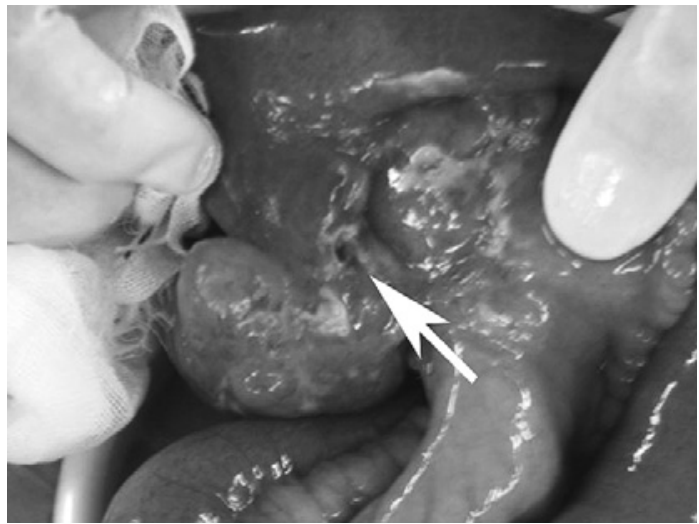

めなかった。

以上より，穿孔性腹膜炎を契機に発症した回腸 重複腸管と診断した。

術後経過：術後経過は良好で第 9 病日に退院と なった。

\section{考察}

重複腸管 (duplications of the alimentary tract) とはLadd ら により提唱され，舌根部から肛門に 至る全消化管に発生する比較的まれな先天性疾患 で，胎生期にて完了する原始腸管充実期からの空 胞形成癒合不全によって発生する憩室である。定 義は，1. 平滑筋により覆われている，2. 内面に 消化管粘膜を有している，3. 正常消化管に接し, 筋層を共有する, と定義されている。一般的には, 腸間膜側に位置し，平滑筋層は隣接する腸管と共 有し, 腸管と共通の血管で栄養されているものと されている。しかし近年では，隣接していない症 例でも重複腸管に含められている. 回腸重複腸管 は同じ真性憩室の Meckel 憩室との鑑別が必要で ある. 存在部位, 血行支配, 固有筋層の共有の有 無にて行われるがときに鑑別は容易でない. Meckel 憩室では腸間膜反対側に存在することが 多く，上腸間膜動脈からの分岐の臍腸管動脈によ り栄養される。一方, 重複腸管では多くは腸間膜 側に存在し, 隣接腸管と腸間膜を共有して血行支 配をうける。また，固有筋層の共有があれば重複
Fig. 4 a : Macroscopic appearance of the resected ileum. There is a diverticulum in the mesentery side with cystic-like structure. The forceps shows the perforated part. b : Macroscopic appearance of the resected ileum. There are mucinous fluid and very small stones in the $50 \times 50 \times 40 \mathrm{~mm}$ cystic-like structure, and there is no network to the intestinal tract. c : The relations of each part in a schema.
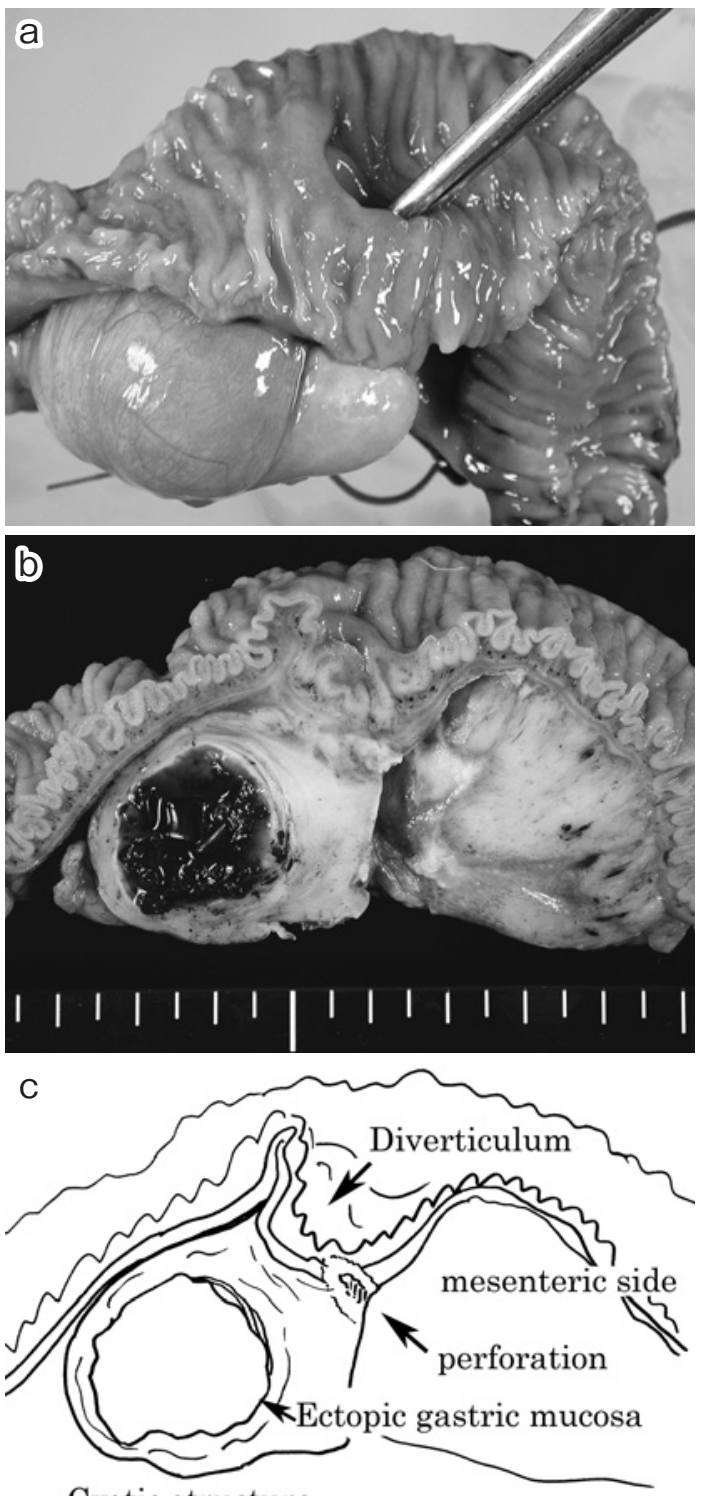

Cystic structure

腸管と考えられる.

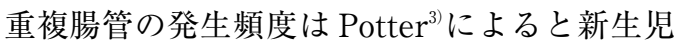
および胎児の剖検例 9,000 例中に 2 例認めたと報 
Fig. 5 a:Histological findings of the specimen $(\mathrm{HE}$ stain $\times 1)$ show that cystic-like structure shared a muscularis propria with diverticulum. b:Histological findings of the specimen (HE stain $\times 40$ ) show that there is the ectopic gastric mucosa inside of cystic-like structure.

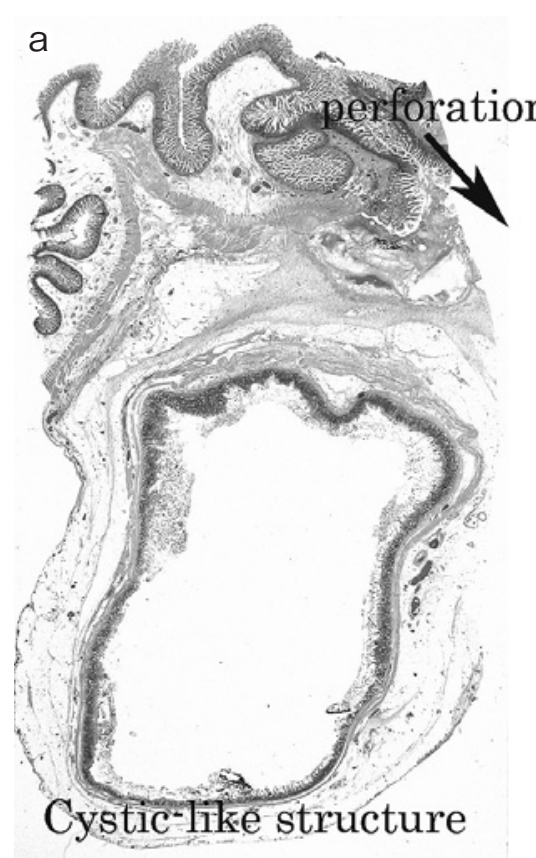

告している. 本邦報告例の集計では長嶺ら ${ }^{2)}$ が 180 例を, 星ら ${ }^{4}$ が 400 例を報告し, 発症年齢は 15 歳 以上で $28 \%, 41.4 \%$ とそれぞれ報告し, 成人発症 例は少なかった。発生部位は回盲部, 小腸, 大腸 の順に多くこの三つの部位で全体の $76.1 \%$, $82.8 \%$ と報告されている. 形状は球状型と管状型 に分類され，回盲部から小腸の重複腸管では球状 型が $79.1 \%$ と多く，隣接腸管との交通は管状型 $85 \%$, 球状型 $4.7 \%$ と報告されている.

組織学的には定義にあるように，平滑筋に覆わ れ，内面に消化管粘膜を有す．消化管粘膜の多く は隣接腸管と同様の粘膜だが，異所性に胃粘膜が 迷入することもあり, 頻度は $18.8 \%$ との報告があ $り^{2)}$, 潰瘍を形成し出血, 穿孔の原因となる. しか し, 穿孔を起こした症例の数は少なく, 長嶺ら ${ }^{2)} に$ よると 180 例中 7 例で穿孔を認め, 異所性胃粘膜 によるものは 2 例と報告されている. 桑田ら ${ }^{5}$ によ ると小腸穿孔の原因は，1)外傷または異物，2)炎 症および潰瘍，3）腫瘍，4）イレウス，5）血管性 病変, 6)その他, として特発性および原因不明と

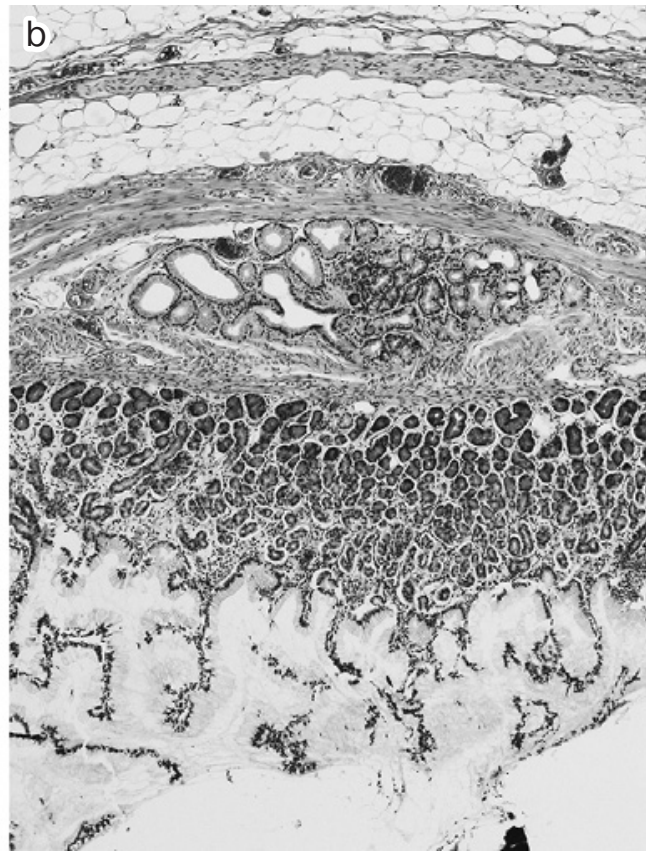

され，重複腸管穿孔の原因も同様にこれらのいず れかが原因となると考えられる。

本症例の診断は, 一見すると管状重複腸管に伴 う腸間膜囊胞とも思われた ${ }^{6}$. しかし, 病理組織学 的には, 囊胞様腫瘤は平滑筋固有筋層を認め, 内 部には全周性に異所性胃粘膜が存在し, 正常隣接 腸管より喤室様に突出した腸管部位と固有筋層を 共有していた。また，正常隣接腸管より櫋室様に 突出した部位もまた腸間膜側に存在した真性憩室 で重複腸管と考えられた。そのため, 正常隣接腸 管付着部から憩室様部, 囊胞様腫瘤までが一連の 重複腸管と診断した. 医学中央雑誌で 1983 年から 2009 年の範囲でキーワードを「腸管重複」,「回腸」 として検索すると会議録も含めて 101 件の文献が 検索でき, 同様に, PubMed でも 1950 年から 2009 年の範囲で同キーワードを「duplication of ileum」 として検索すると 266 件検索できたが，本症例に 類似した形態を示す重複腸管は検索しえず，本症 例は極めてまれな症例と考えられた。この重複腸 管内では櫋室部と囊胞様腫瘤との間で交通は認め 
られなかった．腸管穿孔していた部位の粘膜には 異所性胃粘膜を認めず，周囲に消化性潰瘍もなく 正常小腸粘膜と同様であった．本症例の穿孔した 機序としては, 先に述べた桑田ら ${ }^{5}$ による小腸穿孔 の原因の 1）から 5）のいずれも該当するものを認 めなかった．また，瀬尾ら ${ }^{7}$ が特発性小腸穿孔の定 義として「1）穿孔部腸管壁に肉眼的病変がない, 2)小腸を中心とした腹腔内臓器, 消化管, 腹壁に 小腸穿孔をきたすような病変のない3）小腸穿孔 を起こすような全身的，および血管性疾患がない 4) 腹壁への直達外力, 医療行為による腸管穿孔を 否定しうる5）病理組織学的所見の得られている ことが望ましい，a)穿孔の原因を特定する組織学 的所見がない, b) 粘膜筋層, 漿膜が完全に断裂し, 粘膜は漿膜側に向けて sliding していない, c)腸管 の全層にかけて急性炎症反応を認めても, 慢性炎 症の所見のないこと」と提唱している．本症例で は，腸管壁に腹膜炎による急性炎症所見を認めた が, 病理組織学的検査所見でも明らかな穿孔の原 因は不明で, 瀬尾ら ${ }^{7}$ の定義にあてはまるため, 特 発性の穿孔と考えられた ${ }^{8)}$.

治療方法は重複腸管の楔状切除, 固有筋層を共 有しない場合は重複腸管のみの切除も可能とされ ている ${ }^{9)}$. 本症例では診断目的も兼ね, 腹腔鏡下手 術を選択した。術前診断では Meckel 毠室の穿孔 と診断していたが, 腹腔鏡で観察することにより 回腸重複腸管の穿孔と診断できた. 治療としては, 重複腸管が穿孔していたため, 腸間膜を腹腔鏡下 に切離し, 小開腹を置き $20 \mathrm{~cm}$ ほどの回腸部分切 除術を行い, 開腹術に移行することなく洗浄ドレ ナージを行うことができた。しかし，重複腸管に 穿孔のない場合であれば腸間膜側の血管処理を行 い, 腹腔鏡下 Meckel 憩室手術と同様に, 腹腔鏡下 に重複腸管の切除が可能と思われる ${ }^{7}$. 急性沉発性 腹膜炎，急性腹症を呈している症例などでは腹腔
鏡による腹腔内観察により多くの情報が得られ， その後の治療に役立つと思われる．重複腸管症に 対しての腹腔鏡下手術の報告例はまだ少ない(10)11 が，今回，我々が行った重複腸管に対する腹腔鏡 補助下手術は診断, 治療にも大变有用であると思 われた。

最後に, この主旨は第 27 回愛知臨床外科学会 $(2007$ 年 2 月, 名古屋)にて発表した，稿を終えるにあたり, 病理学 組織学的御指導を賜った伊藤誠先生に深謝いたします.

\section{文 献}

1) Ladd WE, Gross RE : Surgical treatment of duplications of the alimentary tract, enterogenous cysts, enteric cysts, or ileum duplex. Surg Gynecol Obstet 70 : 295-307, 1940

2）長嶺信夫，宮城 靖，遠藤 嗾ほか：消化管重複 症一症例報告並びに本邦文献報告 180 例の統計 的観察一. 外科診療 $19: 466-472,1977$

3) Potter EL : Cause of fetal infant death. Edited by Potter EL. Pathology of the Fetus and the Newborn. The Year Book Publishers, Chicago, 1952, p 54-57

4）星加奈子, 太田貢由, 金村栄秀ほか：下血を契機 に発見された回腸腸管重複症の一例一本邦報告 例の検討も含めて一. 日本大腸肛門病会誌 55 : 43-46, 2002

5）桑田圭司, 岡本英三：小腸穿孔. 外科診療 22 : 667-672, 1980

6）名和正人, 土屋十次, 浅野雅嘉ほか：仮性腸管膜 囊胞を形成した小児消化管重複症の 1 例. 日臨外 会誌 $65: 2242-2245,2004$

7）瀬尾泰雄，有地茂生：特発性小腸穿孔の 1 治験 例。日臨外医会誌 $55: 1809-1813,1994$

8）竹中博昭, 北田浩二, 小野田雅彦ほか：穿孔性腹 膜炎を生じた小腸真性悡室症の 1 例. 日臨外会誌 $65: 2134-2137,2004$

9) Norris RW, Brereton RJ, Wright VM et al : A new surgical approach to duplications of the intestine. J Pediatr Surg $21: 167-170,1986$

10）冨田英里, 宮本康二, 清水幸雄ほか：腹腔鏡下に 切除した消化管重複症の 1 例. 日内視鏡外会誌 $8: 250-255,2003$

11）田中千恵, 藤原道隆, 中山吾郎ほか：腹腔鏡下に 切除しえた成人出血性回腸重複腸管の 1 例. 日内 視鏡外会誌 $12: 613-618,2007$ 


\title{
Laparoscopic Operation for the Perforated Duplication of Ileum in Adult
}

\author{
Hirotaka Miyai, Tetsushi Hayakawa, Yasunobu Shimizu, Moritsugu Tanaka, \\ Shinya Tanimura, Minoru Yamamoto, Mamoru Morimoto, Ken Tsuboi, \\ Takafumi Sato and Kenta Saito \\ Department of Surgery, Kariya Toyota General Hospital
}

We report a case laparoscopy-assisted surgery for adult duplicated ileal perforation. A 38-year-old man seen in an emergency for sudden abdominal pain onset was found in palpation to have severe abdominal tenderness with rebound tenderness and guarding. Abdominal enhanced computed tomography (CT) showed an inflammatory cystic-like tumor in the left abdomen near the navel and very small amount of free air diagnosed as panperitonitis due to Meckel's diverticulum perforation and requiring urgent laparoscopic surgery that day. Laparoscopy showed a perforated diverticulum with a cystic-like tumor about $80 \mathrm{~cm}$ from the ileum toward the mesenteries, necessilating partial ileal resection and appendectomy. The diagnosis was a duplicated ileum with ectopic gastric mucosa inside the cyst-like duplication, but having no pathologically detectable continuity with the intestinal tract. No ectopic gastric mucosa was seen in the consecutive diverticuli but the wall was perforated.

Key words : ileal duplication, intestinal perforation, laparoscopic surgey

[Jpn J Gastroenterol Surg $43: 264-269,2010]$

Reprint requests : Hirotaka Miyai Department of Surgery, Kariya Toyota General Hospital 5-15 Sumiyoshi-Cho, Kariya, 448-8505 JAPAN

Accepted : July 22, 2009 